\title{
DESCRIPTION OF A NEW SPECIES OF OPHELOSIA RILEY WITH SYNONYMIC AND TAXONOMIC NOTES ON INDIAN EUNOTINAE (HYMENOPTERA: CHALCIDOIDEA: PTEROMALIDAE)
}

\author{
P.M. Sureshan ${ }^{1}$ and T.C. Narendran ${ }^{2}$ \\ ${ }^{1}$ Estuarine Biological Station, Zoological Survey of India, Berhampur, Orissa 760005, India. \\ 2 Department of Zoology, University of Calicut, Kerala 673635, India. \\ Email: ${ }^{1}$ samanyu2003@yahoo.com; ${ }^{2}$ drtcnarendran@yahoo.com
}

\begin{abstract}
A new species of Ophelosia Riley, Pteromalidae (Eunotinae) is described from India with synonymic and taxonomic notes on Indian Eunotinae. Affinities of the new species with related species are discussed and a key to the Indian species of Ophelosia is also provided.
\end{abstract}

\section{KEYWORDS}

Hymenoptera, Chalcidoidea, Pteromalidae, Eunotinae, Ophelosia, new species, India.

\section{Abbreviations}

F1-F5 - Funicular segments first to fifth; MV - Marginal vein; $\mathrm{OOL}$ - Ocellocular distance; PMV - Post marginal vein; POL Post ocellar distance; SMV - Sub marginal vein; STV - Stigmal vein; T1-T2 - Gastral tergites 1 to 2.

The subfamily Eunotinae of Pteromalidae includes several beneficial species, some of them used effectively in biological control programmes for certain coccid pests. They are mostly associated with Homoptera, mainly as predators or parasites of eggs of coccids (rarely attack psyllids and aphids) and some times as hyperparasites through Encyrtidae. The subfamily is rich in forms in Australia (Boucek,1988). Narendarn and Mini (1999) reviewed the oriental genera of Eunotinae, which included the description of one new genus and species from India. While rearing some Chalcidoid parasitoids from coccid pests, recently the first author could collect three parasitoid species form coccids on Hibiscus rosasinensis in Maharashtra. The pest infestation was severe on garden plants during summer. The parasitoids were identified as Prochiloneurus javanicus (Ferriere), Anagyrus kamali Moursi (Encyrtidae), Promuscidea unfasciativentris Girault (Aphelinidae) and an undescribed species of Ophelosia Riley (Eunotinae: Pteromalidae) which is described here. Prochiloneurus javanicus (Ferriere) is a hyperparasitoid of the other encyrtid, Anagyrus kamali Moursi. Another species of Ophelosia viz. $O$. hayati Farooqi reported from India is also mentioned in some works on Pteromalidae (Boucek, 1988: 354, Narendran \& Mini, 1999: 21, Sureshan \& Narendran, 2003: 1105, and Sureshan \& Narendran, 2004: 7). On detailed enquiry it was revealed to us that there are no taxonomic descriptions or type material available for Ophelosia hayati Farooqi. Noyes (2001) also not mentioned about the species. So it is clear that the name was put erroneously by Boucek (1988) and subsequent authors and the same treated here as a nomen nudum.

In connection with the present study we made detailed examination of the type species of Ajantha Narendran and the species Ajantha malabarensis Narendran is nothing but Promuscidea unfasciativentris Girault (Aphelinidae) as is also confirmed from the study of the specimens in the present study. Thus we are synonymising Ajantha malabarensis Narendran (syn. nov.) (as junior synonym) with Promuscidea unfasciativentris Girault and the genus Ajantha Narendran as the junior synonym of Promuscidea Girault.

Ophelosia maculata sp. nov.

(Figs. 1-4)

\section{Material examined}

Holotype: Female, Dehuroad, Pune, 20-23.iii.2004, Maharashtra, India, coll. P.M. Sureshan, ex. Coccids on Hibiscus rosasinensis. Paratype: Male, data same as that of holotype.

\section{Diagnostic characters}

Female: Length $1.6 \mathrm{~mm}$. Head and thorax yellowish-brown, gaster brownish-black with slight metallic blue reflection except on petiole, base of T1 and tip of gaster brown; eyes and ocelli chocolate brown; antenna with scape testaceous, remainder pale brown with club darker; all legs (including coxae) yellowishbrown; wings hyaline with veins pale brown, pubescence on thorax and wings brown.

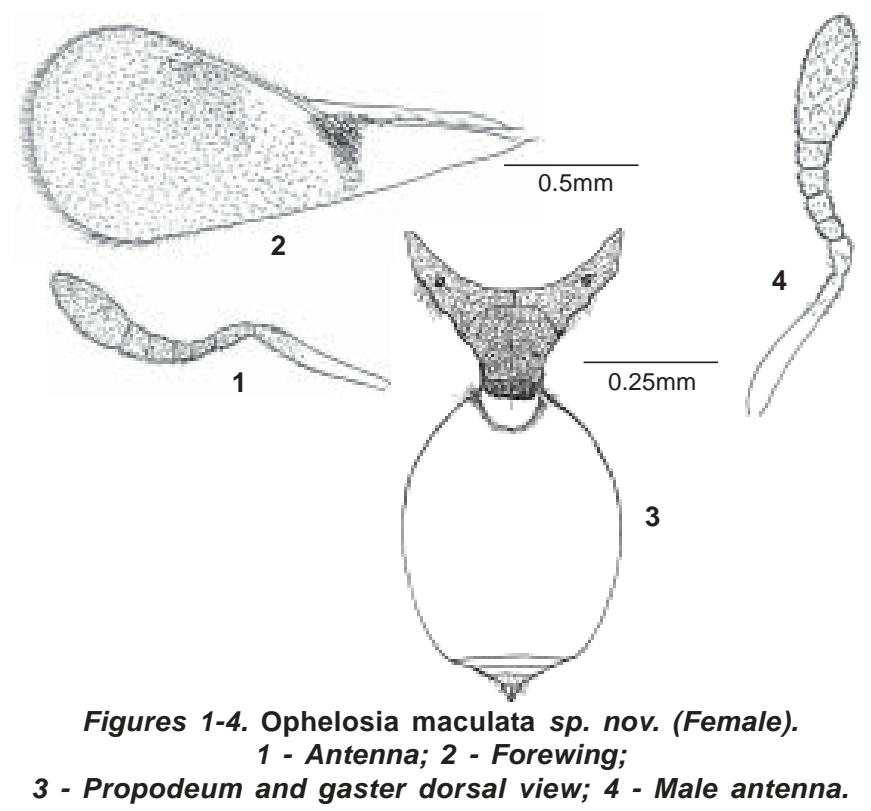

(c) Zoo Outreach Organisation; www.zoosprint.org Manuscript 1310; Received 03 January 2005; Finally accepted 25 March 2005; Date of publication 21 April 2005 
Head: $1.18 \mathrm{x}$ wider than thorax, $2 \mathrm{x}$ as broad as long in dorsal view and $1.4 \mathrm{x}$ as broad as high in front view, alutaceously sculptured, face convex, reticulation on upper face transverse, pubescence sparse and brown on upper face; occiput bordered by a fine but prominent brownish-black carina, latter continuing laterally along temple and lower margin of genae; anterior margin of clypeus slightly convex, clypeus slightly at an upper level than lower margin of head; scrobe deep, reaching little above middle of face. Antennae inserted at upper margin of clypeus but distinctly below ventral edge of eyes, scape slightly arched, as long as eye, formula 11053, pedicel slightly shorter than F1F3 combined, F1 short and anelliform, F2 and F3 equal, F4 and F5 equal and longer and wider than F3, club wider than funicle, three segmented, 1.9x as long as broad and 3.2x as long as F5. Eyes $1.3 \mathrm{x}$ as long as broad (in profile), their upper margin merging with the occipital carina. Malar space broad, $0.42 x$ as long as eye (in profile), malar groove fine, but distinct; genae uniformly convex, strongly receding beyond eyes, finely sculptured; vertex broad with very wide ocellar triangle, lateral ocelli touching occipital carina but close to outer ocular margin.

Thorax: Finely and alutaceously sculptured except on frenal area shiny. Pronotum and mesoscutum covered with sparse brown bristles, Pronotum convex, $2 \mathrm{x}$ as broad as long, collar not margined, bristles on the posterior margin longer and thicker, arranged in a line. Mesoscutum 2.44x as broad as long, notauli groove like, complete; axillae almost shiny with a strong seta on the upper part. Scutellum with one pair of strong setae on the upper part and another pair on the frenal line close to lateral margins, scutellum medially little longer than mesoscutum, frenal line not indicated, posterior margin of scutellum marked by a fine but distinct brown carina. Metanotum broad. Dorsellum broad and triangular, medially divided by a sharp transverse carina, the protion anterior to it is crenulated, posterior triangular portion shiny. Propodeum medially slightly shorter than scutellum with distinct nucha, uniformly punctate reticulate, anterior margin with a very short median carina, spiracles moderate, oval, close to metanotum, callus covered with dense white setae. Prepectus large, triangulalr and shiny. Mesopleuron and metapleuron almost shiny. Fore and hind femora little swollen, hind tibial spur very long and slightly curved inward, little shorter than basitarsus, the latter $2 \mathrm{x}$ as long as the next segment. Forewing $2.3 \mathrm{x}$ as long as broad, marginal fringe moderate, bare in basal one fourth, a triangular brown band with a tuft of strong brown setae below parastigma reaching up to little above hind margin, a broad brown band below stigmal vein, darker on the upper part. Relative lengths of SMV 23, MV 10, PMV 4.5, STV 4.

Gaster: Oval, in dorsal view $1.55 x$ as long as broad (including ovipositor), petiole short, enclosed ventrally by the projecting first sternite; $\mathrm{T} 1$ largest covering $0.8 \mathrm{x}$ of the length; $\mathrm{T} 2$ short, other tergites very short, ovipositor sheath protruded out.

Male: Length $1.3 \mathrm{~mm}$. Resembles female but differs in having head bluish-black like gaster and with metallic reflection; pronotum and mesoscutum dorsally with slight blackish tinge, pubescence whitish, no blackish-brown patch below parastigma and stigma; antennae with four funicular segments, slightly nodose, club longer, about $4.5 \mathrm{x}$ as long as F4, antennae covered with longer hairs, tuft of setae below parastigma less thicker.

\section{Remarks}

This species closely resembles O.crawfordi Riley in general morphology but differs in the nature of antennae except scape pale brown with club darker, pedicel slightly shorter than anelli, F1 and F2 combined, F1 and F2 shorter than F3 and F4 (in crawfordi antennae uniformly testaceous except club brown, pedicel distinctly shorter than anelli, F1 and F2 combined, all funicular segments almost equal in length), propodeal neck short, almost uniformly punctae reticulate, median carina indicated only anteriorly (in crawfordi propodeal neck longer, with strong median carina and submedian carinae anteriorly and remaining areas more finely sculptured), forewing with brown patch at parastigma broad and distinct (in crawfordi brown patch not much broad), gaster blackish-brown with slight bluish reflection, in male head also blackish) (in crawfordi gaster reddish-brown). It also resembles $O$. indica Farooqi but differs from it in the colour of gaster which is blackish-brown, forewing with large circular dusky shade below stigmal vein, brown patch and tuft of setae below parastigma very distinct (with many layers) (in indica gaster reddish-brown, forewing without a dusky cloud below stigmal vein, tuft of setae below parastigma represented by only two to three rows of setae).

\section{REFERENCES}

Boucek, (1988). Australasian Chalcidoidea (Hymenoptera)-A biosystematic revision of genera of fourteen families with the reclassification of species. $\mathrm{CABI}$, Wallingford, U.K., 832pp.

Narendran, T.C. and T.V. Mini (1999). A review of the genera of Oriental Eunotinae (Hymenoptera: Pteromalidae). Journal of the Zoological Society of Kerala 8\&9: 15-28.

Noyes, J.S. (2001). Interactive Catalogue of World Chalcidoidea 2001 (CDRom). Dicks Yu, Bentall Centre, Canada.

Sureshan, P.M. and T.C. Narendran (2003). A checklist of the Pteromalidae (Hymenoptera: Chalcidoidea) from the Indian subcontinent. Zoos' Print Journal 18(5): 1099-1110.

Sureshan, P.M. and T.C. Narendran (2004). Key to the genera of Pteromalidae of India and the adjacent countries (Hymenoptera: Chalcidoidea). Occasional Paper No.229. Zoological Survey of India Pp. 56.

\section{ACKNOWLEDGEMENTS}

The first author is grateful to the Director, Zoological Survey of India, Kolkata and the Officer-in-charge, Western Regional Station, Pune and Zoological Survey of India, Estuarine Biological Station, Berhampur, Orissa for providing facilities and encouragement. We are also grateful to Dr. E.E. Grissell, National Museum of Natural History, USA, for providing the type material of Ophelosia crawfordi on loan and Dr. Mohammed Hayat, Professor, Department of Zoology, Aligarh Muslim University for identifying the Encyrtid and Aphelinid specimens.

\section{Key to the Indian species of Ophelosia Crawford}

1. Forewing without a dusky cloud below stigmal vein and without a brown band below parastigma, the tuft of setae below parastigma represented by two or three rows only; gaster reddish-brown.............. Ophelosia indica Farooqi

Forewing with a dusky cloud below stigmal vein and with a broad brown band below parastigma reaching up to little above hind margin and with many rows of setae; gaster blackish-brown.............. Ophelosia maculata sp. nov. 